\title{
FEAUTURES OF LANDSCAPE DESCRIPTION IN ZHIYENBAI IZBASKANOV'S LYRICS
}

\author{
Dosimbetova Abadan Aliyevna \\ Candidate of Philological Sciences, Assistant Professor, Karakalpak State University named after \\ Berdakh, Nukus, Karakalpakstan,Uzbekistan
}

Article DOI: https://doi.org/10.36713/epra8767

DOI No: 10.36713/epra8767

\begin{abstract}
The article studies the descriptive features of landscape lyrics by the poet $\mathrm{Zh}$. Izbaskanov. Based on the analysis of a number of poem of the poet beautiful aesthetic service of landscape images are revealed. Depending on the genre of characteristics of landscape imagery have been identified. The poet's ability to create an objective image is analyzed on the basis of landscape poems. In the lyrics of the poet, the uniqueness of artistic thought and poetic thinking are studied. KEYWORDS: Karakalpak literature, Modern Karakalpak poetry, Zh. Izbaskanov, Landscape lyricism, lyrical protagonist
\end{abstract}

\section{INTRODUCTION}

Modern Karakalpak poetry, reflecting the spirit of the new era, is developing as an integral part of the artistic and aesthetic consciousness of our society, our spiritual culture.

The poets are conducting research in the way of artistic expression of human spiritual forgiveness, which is the main task of poetry, especially lyricism. Zh. Izbaskanov, a well-known representative of modern Karakalpak poetry, contributes to the ideological, thematic, genre and artistic development of Karakalpak poetry through his educational research. The poet, in particular, is known for his unique educational style in these areas, creating wonderful patterns of landscape lyricism. In this article, we aim to talk about the peculiarities of resin in the use of landscape, the artistic and aesthetic function of landscape images in resin compounds.

It is known that in the science of Karakalpak literature there are a number of research works, scientific articles on the nature of lyric poetry, the theoretical foundations of the image of the lyrical hero. (1) A number of scientific articles were published by scientists on the works of $\mathrm{Zh}$. Izbaskanov, including various of theoretical issues. In this regard, we can mention the scientific articles of T. Mambetniyazov, K. Zharimbetov, Zh. Yessenov, K. Orazymbetov, P. Nurzhanov and others.(2).However, the artistic and aesthetic features of landscape images in the lyrics of $\mathrm{Zh}$. Izbaskanov have not been studied on their own. This describes the urgency of the issue we are going to address in our article.

\section{RESULTS AND DISCUSSION}

Poet Zh. Izbaskanov entered our poetry in the last quarter of the XX century and from that time he became known for his lyrical works in newspapers and magazines. He encouraged his readers with his "Ballads about Horse" (Nukus, 1975), "When Summer Passes" (Nukus, 1979), "From the Notebook of Lyrics" (1982), "Passion for Life" (1987), "Diamond Edges of Love" (1990), "Love Lyre "(1992)," The Day I Waited for "(1993)," My Ways Are Long "(1995),“ My Legend "(1997), Collection of Selected Works (1999),“White Birds ”(2014) and others. Zh. Izbaskanov is the author of several poems. Resin compositions are based on deep lyricism, concise thoughts, figurative descriptions. The poet enriched Karakalpak poetry with his ideological, thematic, genre and form studies and contributed to the development of free verse in Karakalpak poetry as a lyrical form. He is a resin who has his own way of education and personal style in Karakalpak poetry. In particular, Zh. Izbaskanov is known as a master of landscape lyricism, a "singer of nature". Poet's contribution to the enrichment of our literature was appreciated and he was awarded with the Republican Prize named after Berdakh, the titles of folk resin of Uzbekistan and Karakalpakstan.

In $\mathrm{Zh}$. Izbaskanov 's landscape lyricism, the lyrical protagonist is a true lover of the native land, 
who grew up with its nature, expanses, willows, twigs, birds, and loves the nature of his homeland with all his heart, both joy and sorrow which took place in human form. In landscape compositions, resin often depicts spiritual forgiveness by enlivening the scenes of nature, that is, by imparting human qualities.

Landscape lyricism is the illumination of the spiritual experiences of man through the depiction of natural phenomena and the discovery of the relationship between nature and man, society. Poets create an artistic and aesthetic effect of the mixture by changing the colors and appearance of nature. Pupils see the new way of aesthetic beauty from natural conditions with the help of landscape of lyrics.

Zh. Izbaskanov's various aesthetic aims arise particular differences of landscape in compositions. The poet possesses specific writing style of conveying a person's mood and spiritual state through natural forces. The poet had creative researches in this direction and consequently illustrate a wide range of poetic ways.

In his poem "The views of autumn" the hero's spiritual conditions are displayed along with the views of autumn.

Wrapped into silver

Getting quiet around

Having hung just yesterday

Today the leaves are lying.

It seems to be symphasizing

The autumn wind kisses me on the face

Why does the place of love

Destroy those high trees.

Here, the poet describes the lyric hero's spiritual conditions through especially the colors of nature. He moves away the hero's spiritual dejection into nature by saying "wrapped into silver". Usually, autumn is described as golden, but in this poem it is displayed as silver, because the poet tried to convey a despair of autumn and he succeeded in completing it. Clearly, the lyric hero's dejection is passed along with groomy view around. Succeeding in aesthetic results through the colors of nature is a specific particularity of lyrics of landscape. The yellowing of the leaves is an artistic illumination of autumn nature. The lyrical protagonist's spiritual experiences are mixed with nature. In the next lines of the poem, the lyrical protagonist's spiritual experiences are gradually adapted through his connection to nature. The fact that he suffered from a "merciless fate" makes his soul uneasy. At the same time, autumn scenes serve as an artistic and aesthetic service, illuminating the feelings of depression and forgiveness of the lyrical hero. The reason for the lyrical protagonist's depression is due to his "prematurely ended love." The poet assigns a special poetic task to the colors of autumn nature ("silver", "yellow") and events ("stalks") to convey the sorrows of premature, that is, late love.

The poet's poem "Spring Rain" depicts a view of nature - when it is raining. In the poem, when it rains, it is described in such a way that it creates a new, pure, pure feeling for the lyrical protagonist's spiritual world. Usually, raindrops shake the human body, make an unpleasant touch, the person runs away from it and comes to the shelter. It's completely different when you're a lyrical hero. He, on the contrary, "moves forward in the rain," and the raindrops do not shake him, but "move forward." It means that the lyrical protagonist is in love with nature, unique in being able to accept any appearance of his with his heart.

Clouds in the distance,

He walks off the road.

The mysterious pattern of the sky net, They decorate.

In poetry, the cloudy sky, often given as a manifestation of a gloomy mood, creates a new literary look for the poet even from the movement of the clouds. The lyrical protagonist of the poem understands the beauty - the mysterious pattern, which is not taken into account by anyone except the "off-road travel" of the clouds in the distant sky.

In the next lines of the poem, the purification of nature after the rain awakens renewal in the spiritual world of the lyrical hero, pure feelings, passion for the beauty of life, the desire for good.(And in front of me there will be a pleasant surprise - the steppe is beautiful.).

The bluish willows are all around Low rhythms.

A drop of humus on the first leaf It's slippery.

The real dialectic of life is reflected in these series. The sliding of a silver drop on the first leaf of a willow tree after the rain illuminates the season of awakening, the transformation of nature, the rejuvenation of life, the spark of new hope in the heart of the lyrical hero, the feelings of love for life and surroundings. The cheerful depicts the landscape in such a vivid and imaginative way, even we want to grab a drop of silver slipping on the first leaf. It is considered to be the creation of aesthetic beauty from the natural phenomenon which explains the art of creating an artistic image of the resin.

In the composition of the resin, called "Seashore", it creates an aesthetic effect by vividly illuminating the concrete landscape.

The blue sea swayed in the gay,

He quit his job as a gay man.

There was a vibration on his face,

The waves hit the shore.

Longing for her,

Dream, maybe there is,

Constantly striving for Balent, 
Thousands of drops splash. $[4,8]$

The appearance of the sea bet, in which the swam and swam, is beautifully depicted.The poet sees an unusual beauty from the turbulent flow of the sea.The appearance that others do not remind of " drops that chop to the height " on the water sheet . Here is a very wonderful beauty from this view, the aesthetic beauty of a person creates a provocative brilliance of the moon-thoughts, especially the eyeillogical processes that can irritate sensitive souls on the surface of the sea, the poet clearly describes this process, sitting down and teaches the reader the aesthetic zest of landscape views. landscape lirikasin sit in the study and often vividly portray the exact processes of the appearance of nature in it fall.

At the same time, the poet observed that the lyrical process of depicting the natural processes that depend on the seasons of the year depends on the winter, spring, summer, autumn seasons in the lyric poetry, the spiritual experiences of the lyrical hero are different from those that give. At the same time ,the poet observed the depiction of the processes of nature, tied to the seasons in the lyrics, the spiritual experiences of the lyrical hero through the processes of nature, connected to the seasons, give position.

The poem "autumn elegy" describes the sad mood of the lyrical hero through the appearance of autumn. The composition of the poem begins with a series "I think you"and ends with this series.From the same line-it is known that the White lyrical hero has a direction in which the spiritual experiences are directed, that he needs someone, that the feelings of longing are tormented. The trees spilled on the leaves of the evening, buried in the moon Shule, covered with frosts, fly towards the big dream - these are the processes that recognize the nature of autumn. It has completed the service of giving processes of landscape depiction lyrical hero's spiritual world. The spiritual world of the lyrical hero the foliage, frosty, shriveled, covered with Frost to the loss, like spilled trees, the rustling of Thorns is like the screams of his drinking longing. And all this was considered-the appearance of spiritual experiences of the lyrical hero. The spiritual world of the lyrical protagonist is like a field where the leaves have fallen, the fields are covered with frost, the frost is cold, and the willows of the cranes are his inner nostalgia. All of this is a beautiful manifestation of the lyrical hero's spiritual adventures. The lyrical protagonist's spiritual world is shaken by feelings of nostalgia and separation. In the following lines of the poem, the poetic novelty of the poet stands out:

If the leaf of my soul,

It was a dream come true,

I miss you so much

Even if I know you can't deliver ?!

The whirlwind of leaves blowing in the wind is like a mirror in nature. The poet translates it into the spiritual world of the lyrical hero. The lyrical protagonist's heart is full of "distant milk", "the last hope" and his "leaves of the soul" - this is a real emotional state of mind, a different way of thinking.

Zh.Izbasqanov's individual uniqueness in illuminating the artistic content is more noticeable in connection with the scenes of the autumn season in his landscape lyrics. The poet tried to create some kind of beauty from the mirror nature, and the inner world of the lyrical hero was enriched by the mirror landscape.

The poet's new artistic thought is also reflected in the poem, which begins with "A leaf in the eye is a torn leaf - a flame". The object of the painting in the spoon begins with the black willows, and the appearance of the black willows resembles a fat yellow turnip. The beauty of the moon was gradually enhanced, and the yellow leaves were given as "the palms of the willows" and "the palms of the eyes."

My heart was pounding like a willow tree,

Sighing from the long-suffering longing,

Golden eye breath, glowing face,

My face was grinning sharply. [6, 394]

Poet parallels the spiritual world of the lyrical hero psychologically with the scenes of autumn nature. The object of the painting now unites nature and the lyrical protagonist, "the fiery look of the autumn palm makes his face tingle." The yellowing and tearing of the leaves - this condition, which is a daily, opium-like appearance for others, gives a different impetus to the resin, touches his heart and emotions, and this condition is perceived by readers. Both the main theme of the poem and the uniqueness of the landscape lyricism are that the poet teaches his students to take a conscious look at the phenomena of nature, to understand the subtle mysteries of nature. In the autumn, the resin realizes some mysterious idea of the yellow leaves falling from the black willows like a flame and connects it with the phenomena of life.

In a number of autumn compositions, such as resin, the landscape has a special artistic and aesthetic function. In addition to the beginning of "Autumn in the air", the falling of leaves gives the lyrical hero a "mysterious feeling".

\section{Fall around.}

When you think about it

I miss much.

Will the mood fly away? -

The time will pass fast

A sweet feeling. [6, 395]

Underlying this mysterious feeling is whether the lyrical protagonist misses, or longs for a blossoming youth, or regrets the transience of life this is understood in the reader's perception, because it can move him with the "mystery" of the feeling. And "Saske's time. The sun. The sun is silent." In addition, it creates a new image from the appearance of autumn willows. 
The willows are thick,

To stay naked

"Ashamed" perfume...

Poet thinks in a new artistic way, creating an artistic image through animation. He vividly illuminates the struggle for life, the desire to preserve the beauty of youth with the help of landscape images.

In addition to the beginning of "Unatarman", the lyrical hero sees "a thousand dreams" and "nalysh" in the autumn journey of cranes. In this way, the resin expresses the lyrical hero's feelings of love for his homeland through a series of cranes.

\section{CONCLUSIONS}

In short, in the lyrics of $\mathrm{Zh}$. Izbaskanov through landscape depictions, the cheerful lyrical protagonist artistically illuminates the spiritual experiences, inner feelings, creates aesthetic feelings from the scenes of nature.

\section{REFERENCES}

1. Akhmetov S. Karakalpak Soviet poetry. -Nukus: Karakalpakstan, 1988; Mambetniyazov T. Poetry is life, struggle and labor. Nukus: Karakalpakstan, 1993; Orazymbetov K. Artistic research in modern Karakalpak lyric poetry. Nukus: Bilim, 1992; Orazymbetov K. Evolution and typology of artistic forms in modern Karakalpak lyric poetry. - Nukus: Bilim, 2004; Esenov Zh. Sunny sky in my chest. Nukus, Karakalpakstan, 2008.

2. Zharimbetov K. Poetry of the uplifting spirit. Teacher's Way, October 11, 2000; Esenov.Zh Snow White - Purity of Snow, Free Karakalpakstan, February 23, 2008; Orazymbetov K. Lyrics in line with the flow of ideas, Free Karakalpakstan, October 5, 2000; Nurzhanov $P$. Lyrics are my life, whole my soul, The Way of the Master, October 12, 2000.

3. Izbaskanov Zh. From the lyric notebook. Nukus. "Karakalpakstan", 1982.

4. Izbaskanov Zh. Passion for life. Nukus. "Karakalpakstan", 1987.

5. Izbaskanov Zh. Diamond edges of love. "Karakalpakstan", 1990.

6. Izbaskanov White birds. Nukus, "Karakalpakstan", 2014. 